\title{
ACCESS TO HIGHER EDUCATION AND CAREER ADVANCEMENT FOR WOMEN IN THE SOUTH AFRICAN WORK ENVIRONMENT
}

\author{
A. G. Dosunmu* \\ Postdoctoral Research Fellow \\ e-mail: akinolageorge@gmail.com

\section{Dichaba*} \\ e-mail: dichamm@unisa.ac.za \\ *Department of Adult Basic Education \& Youth Development \\ University of South Africa \\ Pretoria, South Africa
}

\section{ABSTRACT}

Women are underrepresented in terms of access to higher education in sub-Saharan Africa. In contrast, six out of every ten first degree and 44 per cent of PhD graduates in all disciplines were South African women. Yet, despite the number of South African women accessing higher education this has not really translated into career advancement in the workplace. Specifically, the article seeks to understand how a higher education degree may facilitate the career advancement of women in the workplace. Two keys concepts underpin the study, namely, lifelong learning and human capital development (HCD). The conceptual framework is thus premised on an understanding that access to higher education for women is critical to HCD, which is a key factor if organisations are to improve their performance. Methodologically, the study used a mixed methods design. Face-to-face interviews were conducted with selected senior women managers and 234 questionnaires were administered to junior workers at a telecommunications organisation in South Africa in 2015. The findings point to the importance of lifelong learning in higher education for women as it assists in reducing gaps in income, accessing senior management positions and, thus, achieving their goals as women. Perhaps the most abiding idea that emerges is that the women in this study displayed a strong sense of ambition.

Keywords: higher education, women, access, equity, opportunity, workplace

\section{INTRODUCTION}

In Africa, gender disparity is manifest in unequal access to higher education and inequitable opportunities for women to attain the higher qualifications required for a successful career (Fielding 2011). In some developing regions of Africa the present enrolment rates ratio is still at the same range (UNESCO 2015). However, the enrolment rates of women in higher 
education in Sub-Saharan Africa are still the lowest in the world by far (Majgaard and Mingat 2012). In addition, throughout the African continent discrimination along gender lines has been firmly established in terms of educational opportunities for women, thus constituting the most wide-ranging injustice particularly in the areas of access and achievements. The current percentage of women accessing higher education in Sub-Saharan Africa is only 25 per cent of total enrolment in higher education institutions (HEIs), which is far lower than both at primary and secondary level (Lumumba 2006).

The problem of access to higher education is linked to socioeconomic, geographic and racial differences among women in South Africa. South African women generally have struggled to make inroads into higher education, having to compete with their male counterparts in terms of access. Meanwhile reports indicate that in past decades just 1 per cent of women in South Africa had the opportunity to access higher education this figure later increased (Moodie 2010). The consistent structural problems experienced in terms of gender inequality is a reflection of profound disparities in institutions of higher learning. In the post-apartheid era the number of women entering HEIs in South Africa has increased; nevertheless, the prospects for women to attain higher positions in workplace are modest (Akala and Divala 2016). In South Africa, the majority of women and girls still struggle to access education and excel at most levels, thus contravening the Constitution which guarantees equality for all (Commission for Gender Equality 2015). Although the South African Constitution recognises education as a fundamental human right, areas of marginalisation still exist within the current education system in terms of access. Recently, enrolment rates of female students accessing higher education have increased, leading to some formidable achievements especially for black South African women (CHE 2009). In contrast with the apartheid era, efforts have been made to ensure a shift from segregation to equity and equality, especially for the groups of women who previously experienced barriers to accessing higher education. Furthermore, the Department of Higher Education and Training (DHET) white paper of 1995 prefaces the need for nondiscrimination, equity of access and fair chances for women (DHET 2016). Similarly, the inclusion of an equity clause in higher education was aimed at a process of reform to assist HEIs to overcome gender disparity. For instance, the equity paradigm in South African higher education was adopted in order to expand opportunities for women who might have been side lined in the past (Machingambi 2011).

This article explores women's access to higher education by considering the importance of this access in terms of it leading to women later having successful careers and thus possibly creating opportunities for them to compete for higher positions in their career paths. 


\section{HUMAN CAPITAL DEVELOPMENT AND LIFELONG LEARNING: CONCEPTUAL CLARIFICATION}

The human capital development (HCD) conceptualised people as very important resource to develop in order to achieve overall goals and objectives of the organisation (Martinez 2014). Within this premise, Martinez has argued for HCD application to be more people-oriented; because it is the individual employee that will assist an organisation to create values and benefits it desired. The idea of Martinez on how people should be treated however require further analysis. This is where gender analyse plays an important role. In this context, organisations are expected to consider professional development it employees as core strategy. The reason for this is that employees who are not motivated are likely to change their jobs or remain unproductive in the organisation. From gender perspective, discrimination or unfair treatment could also lead to high job turnover among the female employees. The construct of HCD understands this dynamic to determine what make an employee could not only stay in organisation but to also become productive. Literature has identified lifelong learning as motivating factor in most cases and as one of the reasons most female employees will feel welcomed in the organisation. Career advancement of female employee particularly in a male dominated industry is crucial. Broadly, when an employee could foresee career progression, there is possibility that such an employee will remain committed. Career progression indicators likelihood of having access to training and other opportunity to grow - it is a motivating factor when an employee makes decision about organisation to join. Hence, human capital development is a big factor and good strategy in organisation (Martinez 2014).

In trying to deepen into the conceptual analysis of the importance of HCD and lifelong learning, Stockley (2008) also challenged organisation to commit more resources toward developing people because organisation with physical assets but that lacked resourced people will experience slow growth or collapsed. The main challenge to envisage while trying to focus on the core ideas of HCD and lifelong learning is how to ensure they will contribute to performance and development for both the employees and organisation. In most cases, it requires having management who understand the complexity of managing people and limited resources to achieve these goals. Within this framework, policy goals of the organisation should not ignore importance of effective health care, training and development for employees (Stockley 2008). In view of this, Adayana $(2009,2)$ coins HCD as tool and a strategic tool for organisation to achieve set goals without losing sights of professional development of people. This points to importance of aligning employees' goals to that of the organisation. The assumption is that organisation will develop as employees are developing. In practice, this may not be the case if it is not well planned and managed. Both parties have goals to achieve. 
Organisation will use training, attractive incentives and bonuses for example to motivate employees to perform. What goes into performance is far beyond just training employees. There may be other factors which organisation need to pay attention to. The issue of gender discrimination at workplace needs attention for instance. Training a female employee may not necessary contribute to performance if this employee is constantly treated differently. Therefore, lifelong learning is an investment and assets for the organisation, at the same time could be a liability in certain instances or if gender discrimination is ignored (Kefela and Rena 2007). As a result, HCD should be not only be used to maximise profit for the organisation but to provide benefits for everybody working in such organisation.

There are a number of ideas around functionality of HCD for organisation in the body of literature. Majority of these ideas speak to $\mathrm{HCD}$ as engine of economic development and growth through training and education. The assumption is that if HCD is used to achieve this goal, it is likely that poverty and other socio-economic problems may be resolved. Another important idea that have emerged from the study of HCD is that it improves quality of life of people when women, in particular, is placed at the centre of economic development. Therefore, Lucas (1988), Romer (1990) and Barro and Jong-Wah (1993) used endogenous growth models to reimagine HCD and coin it as economic development driver in the face of limited resources. In the same vein, Adebiyi and Oladele (2005) restated these facts about HCD. What is interesting about it is the believe that HCD must adapt to workplace situation and should not also create burden of workload, for example If this aspect is well managed, employees are likely to adapt and adopt innovative way of doing things (Nwachukwu 2007). Thus, HCD promotes skills acquisition and workplace development if special attention is paid to factors that will make it effective (Sharma 2004).

By definition, lifelong learning is activities of a group of people within a social, economic and political place that brings about change regardless of location or context (Aitcheson 2003, 165). This definition is further illustrating the importance of learning from childhood to adulthood. Therefore, the behaviours of people within an organisation is not just what they have learnt or have to still learn when they become an adult but it is also a function of the learning they have been exposed in their early life. This analysis also explains whether a particular employee will learn fast or slow at workplace. Back to discussion about women, most of them have experienced structural inequality as a result of where they were born and the kind of orientation they have been exposed to. Even in their adult stage it is likely that they may still struggle except they unlearn certain believes about their identity. Thus, lifelong learning for women at workplace should focus not only to make them do job well or to get promotion, but should also be targeted at changing past behaviour in order for them to break future barrier at 
their workplace. If women are empowered, society will be transformed. This is the reason lifelong learning and HCD are a good mix to use to bring about this change (Smith 2002).

Lifelong learning in certain instances may be structural and informal. The structural side of lifelong learning looks at wider context of workplace scenario and it is determined in such a way to bring about absolute improvement to an individual professional career and condition of living. Meanwhile, the informal explanation of lifelong learning focuses on making positive impact or impression on individual working in an organisation, society and the organisation itself (Margaret 2008). Regardless of how lifelong learning is defined in the body of literature, it is basically more of drives that bring about desired change for individuals, society, economic and development. What this means for developing countries is that it provides opportunity to educate and create more opportunity for further education at different levels to ensure continuous learning for economic development purpose. The application of this to women in a formal organisation is simply to seek change from gender perspective and within the African context.

In the context of the study, HCD could be used to brake number of barriers facing women at workplace from accessing training opportunities that could have helped them to succeed in their career. Further to this, it shows that lifelong learning is an important component of HCD that can be used for majority of women who have been denied access to managerial positions in the past.

\section{EMPLOYMENT EQUITY AND CAREER PROGRESS OF WOMEN}

Booysen (2007) reveals that the advancement of women to executive positions in South Africa may no longer be seen as an option but as a requirement. The South African Employment Equity Act 55 of 1998 redressed the scales in favour of previously disadvantaged individuals in respect of access to opportunities in the workplace, while companies also came under pressure to meet employment equity quotas.

Employment equity legislation is a key instrument for addressing the legacy of inequality, disadvantage and segregation of particular groups such as women in the labour market (Allen $2001,19)$. It is evident that the fact that certain groups (women) are or have been disadvantaged has a broad economic impact on society. Individuals who are disadvantaged frequently never reach their full potential, neither do they realise their potential earning power and they may even have to rely on assistance. In other words, if companies are to become both effective and efficient, it is imperative that their internal organisation is such that their corporate structures provide for ways in which to build the strengths of undervalued people, often women (Equal Opportunities Commission 2002, 5). Ziehl (2000, 3) notes that equal employment opportunity 
has been the focus of debates by scholars and academics regarding the creation of a non-sexist and non-racist environment. The reason for an equal opportunity policy is to identify and abolish discrimination in the society.

The Employment Equity Act regulates activities within organisations to ensure that no one is treated unfairly. Part of this regulation is to redress the inequality of the past where women in particular had been denied access to managerial positions. The Act therefore request compliance and ensure continual monitoring of this policy (Martha 2010). After 1994, South Africa aimed to transform economic, social and political systems to stop discrimination on the basis of race, gender and so on. This has led to policies where organisations across South Africa have been required to give preference to previously disadvantaged groups, mostly black and women to access employment fairly. This policy is symbolic to some extent. In practice, a number of women for instance, have gained employment in male dominated industries, at the same time, majority of them are still struggling to attain senior management position due to a certain form of discrimination. The purpose of affirmative action in terms of given preference to certain group of people is to address this problem (Louw 2015). The imbalance between the policy and what is actually happening in practice is calling for proper monitoring and implementation of these policies (Makgoba 2005, 21).

In South Africa, employment equity legislation has forced organisations to create and implement practices focused on the opportunities and challenges of diversity and equity targets (Oosthuizen and Naidoo 2010). However, effective diversity programmes extend well beyond merely hiring a diverse workforce. They also include creating family-friendly workforces, providing diversity training and developing mentoring programmes. With the face of the workplace changing as a result of programmes of affirmative action and equal opportunity, organisations have made efforts to include in their management structures people from historically disadvantaged backgrounds and who were previously denied such access.

\section{WOMEN IN LEADERSHIP POSITIONS IN SOUTH AFRICA}

Historically, racial hierarchies in South Africa embedded within the apartheid structure created distinctive social locations which structured racial and gender experiences in the workplace differently (Reuben and Bobat 2014). However, South Africa's unique social history has raised the prospect of distinct differences in the perceptions of executive stereotypes across gender and race (Booysen and Nkomo 2010). In the past it was reported that the unequal power relations between women and men in the workplace was as a result of the previous apartheid system that was simultaneously established in terms of a gendered hierarchy (Mgcotyelwa 2012). On the other hand, African women were largely confined to domestic work rather than 
professional jobs. Data reveals positions of leaderships among gender and race in South Africa, specifically: Black men make up 10 per cent of top management and 12 per cent of senior management, while white men represent 61.1 per cent of top management and 47 per cent of senior management, followed by white women who comprise of 12 per cent and 18 per cent, respectively (Fajardo and Erasmus 2017). Black women are the most underrepresented groups on all levels of professions and management. In top and senior management the current representation of black women is 4 per cent and 5.4 per cent respectively. In South Africa women make up 52 per cent of the total population but the information communication technology sector for instance, which is strongly gendered (James et al. 2006), was still very much a male domain in 2005. More than 81.4 per cent of those doing core information communication technology work were men and only 18.6 per cent were women (James et al. 2006).

A similar picture holds for gender transformation in South African newsrooms, where South African women are under-represented at only 18 per cent of newsroom staff (Daniels 2013). Women are still scarce in the upper echelons, with less than 30 per cent in top management positions and roughly one in three in senior management positions (Valie 2018).

As such, reports reveal that 31 per cent of South African companies have no female representation in senior management positions (Fajardo and Erasmus 2017). Recently, a report on women in leadership by the Businesswomen's Association of South Africa (BWASA) (2017) indicated that only 7 per cent of executive directors are women, while 22 per cent of board directors are women. According to the BWASA report, only 10 per cent of South African CEOs are women, while reports on companies listed on the JSE show that the percentage of women on boards of directors has dropped by 2.2 per cent. Reports indicate that there was only a slight increase in women's representation in leadership roles in South Africa from 26 per cent in 2004 to 28 per cent in 2017 (BWASA 2017).

Accordingly, it is very hard for women to reach the top management levels despite the fact that women in South Africa now hold more qualifications. Thus, it would seem that a glass ceiling exists in South African workplaces which is preventing women managers from advancing to the top management.

\section{METHOD}

For this research, a mixed methods research design was adopted to examine and analyse in detail how women managers and junior workers experience career development through access to formal and informal learning. For the data collection purpose, women managers were chosen and sampled in order to understand the factors that enabled their progress to senior positions. 
Junior women workers were likewise chosen in order to understand how they were planning to build their careers. Accordingly, an interview method was chosen for data collection with respect to the women in senior management positions, with the in-depth conversations with the participants providing us with insight into the challenges and demands they had faced along their career paths. A survey technique (a questionnaire) was also adopted to obtain data. Thus, our aim was to obtain data from women who had "arrived" and those who were "not yet there" but were perhaps planning to become senior managers.

The population comprised women employees in a selected corporate organisation in South Africa. The sample selection included all categories of women employees, both junior and senior. We used purposive sampling to select women in senior managerial positions. In addition, a simple random probability sampling technique was used to select women junior workers in a corporate organisation in South Africa. The sampling ensured equal opportunity of women being selected from the total population. A total of 234 employees were quantitatively sampled generated from total population of 1500 women junior workers. Of the 234 questionnaires administered 133 were returned. Two senior women managers were qualitatively sampled in order to complement the quantitative data. Data analysis was based on returned questionnaires using correlation statistical analysis to determine the relationship between access to education and women's career advancement.

Both quantitative and qualitative data were integrated into a coherent whole, while data obtained through quantitative means were displayed in tables. Data correlation as applied to this study entailed both quantitative and qualitative data being harmonised to give a deep understanding of the data obtained. It is these understandings of data analysis that informed the method and process for the analysis of the data collected from the participants of this study.

\section{FINDINGS AND DISCUSSION}

It emerged from the information gathered from the interviews and questionnaires that access to formal and informal learning played a key role in the career progress of women in the workplace, while internal and external motivation was also vital for the professional advancement of women. The findings revealed a link between ongoing learning and the professional advancement of women, thus demonstrating that the more opportunities available for women to participate in learning projects the greater the chance that their careers in the corporate world will progress.

As may be seen Table 1, 61 (45.9\%) of the respondents were in possession of diploma certificates, while $56(42.1 \%)$ had bachelor degrees. This suggests that the female workforce is dominated by women who possess diploma certificates and bachelor degrees and would be 
ambitious about their careers. Thus, it is likely that the majority of the respondents under 30 and in their early 30 s and with either a diploma certificate or a bachelor degree would tend to be focused on their careers in the workplace and also eager to explore the available opportunities in order to further their careers in the corporate environment.

Table 1: Educational qualification of respondents

\begin{tabular}{|l|c|c|}
\hline Qualification & Frequency & Percentage \\
\hline Doctorate & & 4.5 \\
\hline Masters & 6 & 42.1 \\
\hline Bachelor & 56 & 45.9 \\
\hline Diploma & 61 & 7.5 \\
\hline Other & 10 & 100 \\
\hline Total & 133 & \\
\hline
\end{tabular}

The table shows that six $(4.5 \%)$ of the respondents had master degrees while none of the respondents had a doctoral degree. However, $10(7.52 \%)$ of the respondents did not have qualifications listed in the options. This suggests that a large cohort of women in the corporate workforce does not have the qualifications required to pursue their careers further in the workplace. This means that majority of the respondents still struggle to attain higher qualifications as most of the women had only obtained a diploma qualification, which might not give them enough opportunities to compete with their male counterparts to attain higher positions in the work environment.

Table 2: Continuous learning and career progress of respondents

\begin{tabular}{|c|c|c|}
\hline Continuous learning & Frequency & Percentage \\
\hline Yes & 127 & 95.49 \\
\hline No & 4 & 3.01 \\
\hline No response & 2 & 1.50 \\
\hline Total & 133 & 100 \\
\hline
\end{tabular}

In responding to how continuous learning has helped to progress in their career, majority (95.48\%) of women believed that more learning opportunities have enhance their career progression. This shows that access to training or any form of continuous learning could make women achieve promotion and career advancement. This finding supports most of the arguments in the literature that women are likely to perform better, feel welcomed and also advance to senior positions if they are given opportunity to further their studies. However, what this finding did not reveal is the nature of the training. The assumption is that these women must have been given opportunity to further education in the areas that will benefit them and 
the organisation because this is the essence of HCD and lifelong learning.

In view of the findings, women are likely to be more productive if they are given opportunity to learn on the job. In South Africa where discrimination for women is prevalent, further education is the key and also a significant factor to consider for career development.

However, continuous learning for women employees on the job is considered to be linked to women's access to learning within and outside the workplace, which may serve as a mechanism for them to advance in their career paths. From the findings it would seem that a large majority of the respondents valued learning as a possibility for enhancing their career development.

Table 3: Personal barriers affecting the respondents' career progress

\begin{tabular}{|l|c|c|}
\hline \multicolumn{1}{|c|}{ Personal barriers } & Frequency & Percentage \\
\hline Lack of career aspirations & 46 & 34.59 \\
\hline Lack of education & 22 & 16.54 \\
\hline Poor self-esteem & 46 & 34.59 \\
\hline Leadership style & 15 & 11.28 \\
\hline No response & 4 & 3.00 \\
\hline Total & 133 & 100 \\
\hline
\end{tabular}

Table 3 shows that some (34.59\%) of the respondents believed that inability to aspire for career development affected their career progression or it is a major barrier for them. The low-selfesteem could also be attributable to level of education of these women. A quite number of respondents cited a lack of education (16.54\%) also as a major obstacle that hinders their career development. This finding indicates the need for retraining and reskilling of women in order for them to have confidence to aspire to grow. This is the aspect of lifelong learning that cannot be ignored. On the other hand, leadership style (11.28\%) of managers also cited as another challenge to career aspiration and progression in the workplace. One interesting thing to learn from this finding is that women were less likely to desire senior positions or promotion. A lot of these have to do with fear of rejection, poor self-esteem, education status, and leadership style of management.

From another finding, it was discovered some have managed to access further education. For instance, one of the female participants has just recently obtained a master's degree in business administration at the time of this research. As a result, it was revealed that the advanced education earned her promotion and also confidence to aspire for a bigger position. In a male dominated industry like Technology Company, the competition could be so intense and breaking the status quo may also be a major challenge for women who have aspired to in such an organisation. This finding suggests that further education changes career psychology of 
women in this organisation as they become more confident and also feel ready to compete after they have acquired more knowledge and skills in related fields. All participants confirmed that access to further qualifications and advanced degrees after they have completed them gave access to higher positions.

Based on the literature, on-the-job learning is crucial for human and organisation development. This can be confirmed through these findings. However, the literature and also the finding is quite about the kind of education and skills obtained by these women in particular. The assumption has been that they have obtained advanced degree while working. This is evidence by a woman who indicated has obtained a master's degree in business administration (MBA). An MBA degree is a perquisite to be promoted to a senior management positions in many organisations. The trend of trying to obtain an advanced degree such as MBA will contribute to the strategic development of the organisation and also to the career of women who have obtained these degrees. Hence, lifelong learning and HCD is not just about more qualifications, but it is about qualifications that matter. This is the responsibility of the organisation to ensure that employees have obtained qualifications that will make them function better in their respective jobs.

Lifelong learning and HCD have emphasised mutual benefits between employee and the organisation in the literature. In other word, organisation must benefit from the investment on education for its employees. The finding of the study shows majority of women believed they have personally benefited from training and education that the organisation has made available to them. The skills they have obtained are expected to be transferred to job and development of the organisation respectively. Whether this is happening in practice after the training is not echo by this research. However, the enthusiasm shown by the women who have been trained or had access to further education indicates high chances that they will contribute to the development of the organisation if they are given opportunity to take position of leadership.

The junior women workers who have been interviewed essentially indicated and emphasised motivation as important factor to be considered by their organisation. By motivation, they explained that they need to be motivated to perform and this is largely depending on the opportunity that are available to them. Among other things, they would want to be trained in order to be motivated to do more for the organisation. By this, it means training and education will boast their moral to aspire and be confident to take senior positions in future. This revelation could be translated into strategy for the organisation by trying to link the need of employees in the area of training to organisation development. As mentioned previously, if properly managed it may translate to development for individual working in this organisation, the organisation itself and society at large. 


\section{RECOMMENDATIONS}

This research focused on lifelong learning, human capital development and career advancement of women working in a telecommunication organisation. It conceptualised lifelong learning and human capital development broadly and in some way it narrowed it down to how learning could help organisation achieve its strategic goals. The findings show that both the organisation and women have gained access to further learning. Therefore, they have roles to play for organisation development. Interestingly, women in the study are likely to drive change in their organisation because of the quality of training and education they have been exposed to. This is an expectation though. In reality, this expectation should be managed to align to the strategic goals of the organisation.

The research and development department of this organisation will need to rethink about using the strength of women within the organisation to drive change that they desired. Women in this study were excited after they gained advanced qualifications, an indication that will be willing to work harder if they are given opportunity to lead. Therefore, this should be seen as opportunity not threat for the development of the organisation and people working there.

Finally, training and education should be focused on helping employee to function better in their jobs and should also provide pathway to senior positions. Though an MBA degree is good, however, an employee who need to lead a finance department in future will need to be more grounded in finance and accounting not general MBA. This means more attention should be paid to what kind of education and training that will benefit career progression of employees, especially women. Otherwise, it may just be wasted resources if after training these women cannot still qualify for promotion because they lack certain technical skills due to the kind of qualifications they might have obtained.

HCD has been studied in relation to challenges women face in their work place and how it can be used to help women to progress in terms of their career. It should be noted that there are a number of factors that can make this work or will affect it from working. In this study, attention is drawn to the kind of training and leadership style needed for this change to happen. Therefore, environmental condition of the organisation is the overarching factor to make both the HCD and lifelong learning effective.

\section{CONCLUSION}

This article provided exploratory and analytical discourse of HCD and lifelong learning from gender perspective. Among other things, this study challenged employment act and affirmation action policy. While these policies provided opportunities for disadvantaged groups in the 
society especially women to access education and grow their career, it has also ignored fundamental strategies that will make it work. Many women who have accessed jobs for instance struggled to grow due to a number of factors. HCD instead takes lifelong learning seriously and this is what this article is advocating. The conclusion is that employment act that provides opportunity for women to secure job is not just enough. Continuous monitoring also is necessary to make sure that women in particular have access to continuous learning that will give them further opportunity to grow in their various organisation. Therefore, policy only is not enough, strategies to implement these policies across the broad is greatly recommended.

\section{REFERENCES}

Adayana. 2009. Optimizing human capital development. http://www.adayana.com/sites/ default/files/docs/Optimizing\%20Human\%20Capital_Final_2

Adebiyi, M. A. and O. Oladele. 2005. Public education expenditure and defence spending in Nigeria: An empirical investigation. http//www.saga.cornell.educ/saga/educconf/adebiyi.pdf (Accessed 10 February 2010).

Aitcheson, J. 2003. Adult literacy and basic education: A SADC perspective. Adult Education and Development 60: 161-170.

Akala, B. and J. J. Divala. 2016. Gender equity tensions in South Africa's post-apartheid higher education: In defence of differentiation. South African Journal of Higher Education 30(1): 1-16.

Allen, J. V. 2001. Women's rights movement as a measure of African democracy. Journal of Asian and African Studies 36(1).

BWASA see Businesswomen's Association of South Africa.

Businesswomen's Association of South Africa. 2017. Women in leadership census. bwasa.co.za/wpcontent/uploads/2018/04/2017-BWASA-CENSUS-report.pdf

Barro, R. J. and L. Jong-Wha. 1993. International comparison of educational attainment. Journal of Monetary Economics 32(3): 363-394.

Booysen, L. 2007. Managing cultural diversity: A South African perspective. In Diversity in Africa: The coming of age of a continent, ed. K. April and M. Shockley. Basingstoke: Palgrave Macmillan.

Booysen, L. A. and S. M. Nkomo. 2010. Gender role stereotypes and requisite management characteristics: The case of South Africa. Gender in Management: An international Journal 25(4): 285-300.

CHE see Council on Higher Education.

Council on Higher Education. 2009. Higher education data. https://www.che.ac.za/focus_areas/ higher_education_data

Commission for Gender Equality. 2015. The African gender development index (AGDI). South Africa country report.

Daniels, G. 2013. State of the newsroom South Africa. Disruptions and transitions Journalism.co.za/ new/wp-content/uploads/2018/03/State of the newroom

DHET see Department of Higher Education and Training.

Department of Higher Education and Training. 2016. Policy framework for the realisation of social inclusion in the post-school education and training system. Government Gazette, 22 no. 40496.

Equal Opportunities Commission (EOC). 2002. Facts about men and women in Great Britain. Manchester: Equal Opportunities Commission.

Fajardo C. and M. Erasmus. 2017. Gender (dis)parity in South Africa: Addressing the heart of the matter. 
www.bain.com/insights/gender-disparity-in-south-africa/

Fielding, P 2011. Identify gender inequities in higher education in Africa. http://www.fawe.org/ Files/FAW Equal Education

James T., Ronel Smith, J. Roodt, N. Primo, N. Beeby, L. Fok, N. Evans and V. Moutloutsi. 2006. Women in the Information and Communication Technology (ICT) Sector in South Africa. SA pos paper final.doc.

Kefela, G. and R. Rena. 2007. Human capital investment is a continuous proposition: A study of north east African states. Indus Journal of Management \& Social Sciences 2(1): 50-65.

Louw, A 2015. The employment equity act 1998, and other myths about the pursuit of "equality", "equity" and "dignity" in post-apartheid South Africa. Potchefstroom electronic law journal 18(3).

Lucas, R. E. Jr. 1988. On the mechanics of economic development. Journal of Monetary Economics 22(July): 3-42.

Lumumba, A 2006. Empowerment of women in higher education in Africa: The role and mission of research. UNESCO forum on higher education, Research and Knowledge.

Machingambi, S. 2011. Is access to higher education a sufficient condition for social equity in South Africa? A critical analysis. Journal of Social Sciences 28(1): 13-20.

Majgaard, K. and Alain Mingat. 2012. Education in Sub-Saharan Africa: A comparative analysis. https://openknowledge.worldbank.org/bitstream/handle

Makgoba, M. 2005. Bold steps needed to save affirmative action. Sunday Times, January 2.

Margaret, L. 2008. Work based learning: Graduating through the workplace. http://www.cit.ie/ contentfiles/extended/work-based-learning.pdf

Martha, T. 2010. Application of employment equity act and diversity in mining industry. Unpublished master's thesis. North West University.

Martinez, W. 2014. The true meaning of human capital. http://www.deloitte.com/view/en $\mathrm{GT} / \mathrm{gt} / \mathrm{press} / 3 \mathrm{~d} 5$ ea783aab60310VgnVCM2000001b56

Mgcotyelwa, N 2012. Experiences of gender and power relations among a group of black women holding leadership positions: A case study of six government departments in the Western Cape. Unpublished master's thesis. University of Western Cape, Cape Town.

Moodie, A. 2010. South Africa: Advancing women in higher education. University World News (63): 3.

Oosthuizen, R. M. and V. Naidoo. 2010. Attitudes towards and experience of employment equity. $S A$ Journal of Industrial Psychology 36(1): 1-9.

Reuben, S. and S. Bobat. 2014. Constructing racial hierarchies of skill - Experiencing affirmative action in a South African organisation: A qualitative review. SA Journal of Industrial Psychology 40(1): Art. \#1158, 12 pages. http://dx.doi.org/10.4102/ sajip.v40i1.1158

Romer, P. M. 1990. Endogenous technological change. Journal of Political Economy 98(5) part II: S71S102.

Sharma, S. C. 2004. Management system. New Delhi: Khana.

Smith, M. K. 2002. Malcolm Knowles, informal adult education, self-direction and andragogy. In The Encyclopedia of informal education. www.infed.org/thinkers/et-knowl.htm

Stockley, S. 2008. Shiny people. In the Black 78(1): 46. EBSCO Host: http:// serach.global.epnet.com

UNESCO 2015. Regional overview: Sub-Saharan Africa: en.unesco.org/gem-report/sites/gem-report/ files/regional overview SSA

Valie, Z. 2018. Are women rising in senior management in SA. www.iol.co.za/business-report/ economy/are-women-rising-in-senior-management-in-sa-13658424

Ziehl, S. 2000. Affirmative action and equal opportunity policies: The relevance of a dead German. Society in Transition 31(1). 